Journal of Economics and Behavioral Studies

Vol. 6, No. 2, pp. 163-168, Feb 2014 (ISSN: 2220-6140)

\title{
Chinese Economic Development and Leadership Strategy: The Challenges of Creating Competitive Advantage
}

\author{
Kinfu Adisu \\ Fort Hays State University, People's Republic of China \\ kadisu2003@yahoo.com
}

\begin{abstract}
In the last three decades China's economic development have achieved great many things some of which are 73 or more companies among the Global Fortune 500 (E \& Y Report, 2012). This progress accelerated the country second to the US in its ranking. In addition, Chinese companies are expected to represent close to one fifth of all Global 500s by the 2020. The economy consistently grew 10 percent for the past decades and is anticipated to recover from the recent global financial crisis faster than some Western nations (Ju and Mirza, 2012). The economic growth has created debate among two camps; the skeptics are projecting the bust is near, while the cohorts claim to foresee continuity in the general direction. The purpose of this paper is therefore, to examine China's economic development in light of an assertive strategic leadership that created sustainable economic development and distinguish the challenges of implementing a strategy to create competitive advantage through multiple economic systems; a market lead economy and a robust state developmentalism. The main question is; could it be possible for China to continue on the path of economic development and create a competitive advantage? If so, what are the opportunities and the challenges? Examination of the questions by using Institutional theory, leadership strategy, economic growth and institutional development theories indicated that continuity of the economic development depends on an assertive leadership and liberalization. Also, China should look into its own brand, and create unique or differentiated products, methods and processes that can sustain economic development. The local sector has similar characteristics as western market lead economy; that the managers are motivated by financial incentives that are received when their decision lead to an overall profit.
\end{abstract}

Key Words: China, Economic Development, Leadership

\section{Introduction}

The main goal of most developing nation's economic, political and social development plan is to create sustained and competitive environment that will support thriving businesses and allow the individual citizens a modest living condition. It is imperative to understand success or failure of development plans are based on unique conditions present in those countries. While the western economy has been proven to be successful, the 2008 financial crisis have exposed its wide-ranging weakness. Yet, the economic development in BRICS nations, specifically China did not follow the same basic economic guideline presented in the West, therefore is causing debate among scholars. According to Liao (2005) Liberal market theory responds to such economic development differently than coordinated market economy. Hall and Soskice (2001) also explains this difference as a distillation of more durable choice nations make compatible to their specific stage of development. Apparently, the varied economic systems are not new phenomena as there has been difference even among western market economies such as USA and UK in which they followed the competitive market mechanism. On the other hand Japan and Germany implemented coordinated market economies that relied on non market conditions to build their core competencies. Also, considering the difference among the two biggest emerging nations India and China; India chose to pick different route in their economic development plan. India as democratic nation, preferred to implement market dominated economic plan with limited success. On the other hand, China chose to implement dual economic plan comprised of strong state developmentalism and market driven economy without democratic institutions. The Chinese plan so far has produced competitive economy that left scholars with many questions as to how long that will sustain.

China's economic development is showing resilience, especially in manufacturing, foreign trade and financial sectors. Ju and Mirza (2012) stated that the export volume is $3^{\text {rd }}$ in the world reaching 1.4 trillion in 2008. It 
also attracted $\$ 758.9$ billion in foreign direct investment, placed $7^{\text {th }}$ largest in ranks. According to Dobbs, Leung and Lund (2007), the financial markets showed strong growth reaching \$17.4 trillion ranked behind United States and Japan. In addition, the cross border investments are up by $44 \%$ from 2007 level. Compare to advanced economies bank loans have grown by $\$ 5.8$ trillion since 2007 , getting up to $132 \%$ of GDP; $85 \%$ of this lending is to corporations and the rest to households account. The average for advance nations $123 \%$. The general trend of China's economic development may be looking up but there are concerns in what is evident from some indicators. According to Dobbs and et al. (2007), investment at home is expected to have low or negative returns. The stock market did not gain back since the global recession falling by $50 \%$ similar to other emerging markets in which it is subject to sharp sways. It is also evident further challenges are being discussed in many areas. Some of these are: real estate market, currency manipulation, increased growth without wage increase, surplus labor, and low price regime, culture of replication, property rights and environmental issues. Hensize (2000) suggested that the reason for success is because of broad liberalization policy in the last three decades, consistent with conventional justification of economic development. In addition, the following reasons are presented as the basis for explanation of China's economic development. They are social (Chatterjee, 2012), economic (MacFarlan, Edison, and Spatafora, 2003); institutional (Chow, 1997; Liao, 2005; and Hall and Soskice, 2001) and political (Montinola, Qian, and Weingarten, 1996) which are presented in the next discussion.

\section{Literature Review}

Sociology: According to Chatterjee (2012), sociology of capitalism that was developed by Max Weber is not properly explaining practice of modern capitalism. The last two decades has uncovered new experience in global relationships, structures of organization, flexible production, technological innovations and expansion of international financial markets. Yet, this experience did not materialize till the 2008 financial crisis that challenged our normative thinking and working methods. Moreover, the emergence of developing economies of Asia, Africa and Latin America has proved us to look for new and improved answers for the challenges we are facing. Therefore, the classic theories of western social theory may not fully help us explain the relatively new phenomenon of economic development.

Social, cultural, legal and economy: In reference to the challenges of explaining China's economic system, Chow (1997) presents discussion based on economic, legal, cultural and political experience in China. The economy is reflective of the state owned enterprises; collective ownership (townships and villages) and private ownership (by individuals, foreign companies and joint ownership) that are the backbone of the economy. Considering the revenue incentives, some of the state enterprises are efficiently run and financially profitable. This is challenging to the idea that only private firms in capitalist economy are profitable. It is also noted that, there is positive relationship between profit of the firms and economic benefit of management, key to successful performance. Legal: The legal system as practiced in China is considered deficient by Western standard. The most important difference is; under Chinese law, it is enforced by an informal social practice known as guanxi which is relevant for honoring the contract. Guanxi is "a network of human relationships which sets the rules of behaviors among concerned parties" (p323). The application of this method is accompanied by verbal or written agreement that will explain if something happen in the future. Individual rights: This is considered to cause conflict with the common good in Asian countries. It is widely accepted that "welfares of the society is more than a collection of individuals" (p324). Apparently, Western societies consider human rights differently than that of the Asian countries. China, Taiwan, Singapore, and Korea have common experience, such that they had market economies with limited political freedom. Political: While it is not simple to say if market economy functions better under multiparty instead of oneparty system, it is apparent that market economy proved to work in China, Taiwan, South Korea, and Singapore all of which practice one party system.

Economic Development: MacFarlan, Edison, and Spatafora, (2003), studied determinants of economic development. Their work focused on perception and assessments of public institutions and how well they function considering the institutions' impact on public organization behavior. Three measures of institutions are used: first, the quality of governance; second, implementation of legal protection of private property and third, institutional limits imposed on political leaders. They also examined the interaction between institutions and policies: first, they found that greater openness to trade, competition and higher 
transparency which helps the institution to grow and perform better. Second, the strength of the institution has detrimental effect on implementation of the policy. And finally, the weakness of an institution will have greater impact even where policy reforms are implemented. North (1990) defined institutions as, a constraint on political, economic and social interactions. "Good institutions are viewed as establishing an incentive structure that reduces uncertainty and promotes efficiency, contributing to stronger economic performance" (p. 97). In addition, MacFarlan et al. (2003) discussed some principles for high quality institutions. Rodrick $(1999,2002)$ and Frankel (2002) (in McFarlan et al., 2003) listed broad terms that are important for successful market based institutions. These are: protection of property rights, rule of law and fight corruption; regulation of products and financial markets; support microeconomic stabilization; and promote social cohesion and stability. Furthermore, MacFarlan et al. (2003) made distinctively clear that what is appropriate for a country's development is determined upon the particular country's situation. For example; China, Chile, and Central European countries used varied strategic approach to deal with their national economic development. In another way, applicable institutional and strategic methods vary from country to country depending upon specific country situation.

Institutional: Hall and Soskice (2001) identified in their book "An introduction to varieties of capitalism," the difference and similarities of institutions from developed economies. Five distinguishing spheres are presented in which firms develop relationship. Liao (2005) also discussed patterns of economic coordination and control as the main dimensions for various governance structures in different market economies. The first one is, sphere of industrial relations dealing with issues such as wage and labor coordination and bargaining. Second, vocational training and education in which firms need to secure skilled labor and while labor face the decision of which skills to invest into. Third, issue of access to finance and investor assurance. Fourth, inter firm relations, firms' relation with suppliers and customers. Fifth, relationship with own employees and that employees have skills and commitment needed to advance the firm's interest. According to Hall and Soskice, two types of political economies are presented: liberal market economies and coordinated market economies, a range at which many nations are positioned. In liberal market economy, organizations coordinate their activities through hierarchies and competitive market arrangements. Market relationships are characterized by arms-length exchange of goods and services in context of competition and formal contracting (p. 8). In coordinated market, organizations are dependent on non-market methods to coordinate their relationship with others and construct their core competencies (p. 8). This coordination is based on extensive relational or incomplete contracting and exchange of information and cooperation instead of competition (p.8).

Political: Montinola, Qian and Weingast (1996) studied China's political change as the basis for economic success. It is also noted that the performance of the reform resembles that of the high growth East Asian economies. They presented three important points that signified the rationale: one, while the political decentralization increased the power of local government, it also changed the relationship between local and central government that made it difficult to reverse it. Two, as part of the reform, major ideological shift has encouraged the CCP to move away from the Maoist version to a pragmatic market oriented economy. Third, China has for the first time opened its economy. In general, the outcome of these changes brought about a system characterized as federalism, Chinese style. This system is the basis for a special federalism called market-preserving federalism. Market -preserving federalism has a set of conditions that allocates authority and responsibilities among the various levels of government. The following are the main characteristics:

- Clearly defined authority has created an autonomous area of responsibility

- The local government have primary responsibility over its economy

- The national government has overall responsibility to police the market and insure the mobility of goods and factors across jurisdictions.

- Considering the limited revenue sharing among governments, all governments are solely responsible for budgetary constraint.

- The responsibilities are so institutionalized; it cannot be altered by national government unilaterally or under pressure from local government.

The greatest implication of this system is the creation of competition among various jurisdictions. First, no one government has monopoly over the economy and the use of unilateral control cannot be imposed on others. Second, competition is extends to factors of production such as capital and labor, provision of an 
environment conducive to accommodating factor owners, availing of infrastructure and access to market that encourages business to stay within jurisdiction and pay taxes. Third, since budgetary constraint implies bankruptcy of government, they are encouraged to practice prudent fiscal management. Finally, market preserving federalism strengthens the political basis for markets and placing power in the local hands enhances economic prosperity. While decentralization in China is only dependent on political relationships among various governments; Western federalism on the other hand has explicit protection of individual rights, constitutional foundation, political freedom and representative democracy.

\section{Challenges in creating sustained economic growth}

According to Zhang, Ebbers and Mulder (2012), economic changes in emerging countries have drawn attention from the west, and China has been particularly an interesting topic of discussion. Evidently, there is also concern among Europeans and the U.S that there is a continued increase of centralization of production in China.

Strategic Leadership: China's economic development is challenged by variety of issues but extraordinary weight must be given to Strategic leadership and the ability to create vision while learning to adapt to the ever changing global political economy. One is Chinese leaders must realize they are navigating unfamiliar waters through methods that are not previously tested; this is to say market economy with socialist political system is not a common practice but has been so far successful. This does not insure the continued success unless the leadership is willing to open up to the national and global economic pressure, as a basis for new knowledge to map new strategies. This process helps to create what Porter (1990) noted as competitive advantage of nation. Competitive advantage is "created and sustained through a highly localized process. Differences in national values, culture, economic structures, institutions, and histories all contribute to competitive success" (p.74). This implies the fact that China should look into its own brand, and create unique or differentiated products, methods and processes that can sustain economic development. Second is to acknowledge the above mentioned challenges; also listed by Porter as most effective determinant of national competitiveness: labor costs, interest rate, exchange rates and economy of scale must be dealt with to increase the sustainability of the economy. Third is the role government plays in the process of economic development. According to Porter (1990), government should be catalyst and encourage and even push firms to raise their goals for higher competitive performance. Policies that succeed are the once that can create an environment conducive for companies to gain competitive advantage. If the growth trend continues in the same direction, it is obvious the liberalization policy will be incrementally implemented in such a way that Chinese government will have less involvement. This is also reflective of the outcome of the third plenary session held in 2013 that delivered important policy decisions such as; one child policy, less intervention in market and financial institutions. There are also major challenges such as technology and innovation, education and sustainability that need to be examined as part of the strategy to make the country competitive.

Innovation and technology: So far, China has a low cost based and investment intensive growth strategy (Breznitz and Murphree, 2011). If the plan is to achieve sustained economy development, the economy must be innovative and diversified. This plan projects two myths: one is the expectation that new innovation of services and products are the most important factor that will drive the future of the economy. Second, China should imitate the novel product innovation model or face decline. Considering that Chinese companies are at advantage for experiencing global manufacturing process, it is a lot more practical to continue to implement the wide array of secondary innovative activity that can create significant economic value. Brenznitz and Murphree point to the two critical factors that explain the future of high tech economy in China. The first one is the need to understand the shift from vertical integration of firms and production to global production. In fragmentation, companies produce only segments or parts of the whole that can easily be outsourced or offshored. The advantage being a firm does not have to master the whole process of making the product and does not have to raise huge capital to build modern production facility. The second one is the institutional environment where technological innovation takes place, known as structured uncertainty. This is defined as "a political economic condition under which the rules of competitive play are vaguely defined and unevenly enforced" (p. 5). This does not mean there is not law, it simply means the law can be unevenly enforced and can abruptly change which creates uncertainty. Orr and Roth (2013) state that there are important advances 
in innovation emerging from China. While the research and innovation is beginning to show promise, it is clear that there is a need for more management and organization which will help to gain better outcomes. These include; intellectual-property protection, emergence of new generation of talents, and seeking Chinese universities as partners.

Education: Whereas economic development goes hand in hand with training and education, the need for educated workforce needs substantial planning. Chen and Feng (1999) did study "determinants of economic development in China" in which they investigated the need and distribution of education. Their finding indicates that: "Local and central governments should emphasize education in the inner provinces. Not only should a larger share of government expenditures be spent on local school facilities and teachers' compensation, but also a labor system should be established to reward education. The system that retains the best and brightest brains and provides incentives for young people to be educated is one based on market mechanisms that link social status and financial incentives to educational attainment" (p. 13). Pan (2011) also noted the need for educated workforce if Chinese economic development were to be successful. At the same time, he explains the fact that Chinese leaders realize that academic standards in China's higher education system had been damaged by the cultural revolution from 1966-76 and the country has lost competence compared to the rest of the world.

Sustainability: As the country develops its economy, new infrastructures are being built; coupled with increase in population the use of fossil energy becomes handy unless environmentally sustainable form of energy is used. Furthermore, China's government realizes the need to control pollution, protect the ecosystem and build new energy technology. According to Fung and Peng (2012), environmental protection and new energy technologies are very important. As potentially profitable product and much needed technology, Chinese companies should capitalize wind, solar and geothermal energy sources and know how. So far, cost competition and trade mark issues are playing a big role on Chinese solar technology. A very good example can be the resent legal issues with EU and US in regard with trademark infringement.

\section{Conclusion}

In conclusion, the question we presented earlier in the discussion can only be answered dependent upon the proactive actions by the leaders and further liberalization. China's economy is continuing to do well compare with many western nations. While the opportunities are abundant, for this to be realized the above discussed challenges must be met. The political leaders' progress towards liberalization and implementation of practical market measures are encouraging. Review of literature shows that existence of dual economy; liberal market lead and coordinated market did not indicate any weakness, since the main players are the local controlled sectors which exhibited competitive structure. The local sector has similar characteristics as western market lead economy; that the manager is motivated by financial incentive that is received when his/her decision leads to an overall profit. The most important factor is the leadership's ability to decipher the local and global market pressure to continue to create better term in meeting the challenges. China should look into its own brand, and create unique or differentiated products, methods, and processes that can sustain economic development. It is evident the following conditions must be tackled for a sustained economy: less control of real estate market; standardized currency through financial market; evaluate wage, surplus labor, low price regime, culture of replication, property rights and environmental issues.

\section{Reference}

Breznitz, D. \& Murphree, M. (2011). Innovation in emerging economies: China's run of the red queen. books.google.com

Chatterjee, P. (2012). The black Hole of Empire: History of a global practice of power. Princeton University Press.

Chen, B. \& Feng, Y. (1999). Determinants of economic growth in China: Private enterprise, education, and openness. School of Politics and Economics, Claremont Graduate University, Claremont, CA 91711, USA

Chow, C. G. (1997). Interaction of Economic Institutions and Theory: Challenges of China's Economic system for Economic Theory. AEA Paper and Proceedings. 
Dobbs, R., Leung, N. \& Lund, S. (2007). China's rising stature in global finance. McKinsey Quarterly. www.mckinsey.com

Ernest and Young Report. (2012). China in transition: Insights for global companies. China Business Network

Fung, E. \& Peng, Y. (2012). Forces driving China's economic growth in 2012. New thoughts, new strategies, new initiatives. KMPG Global China Practice.

Hall, A. P. \& Soskice, D. (2001). An introduction to varieties of capitalism.

Henisz, W. J. (2000). The Institutional Environment for Economic Growth. Economics and Politics 12(1), 1-13.

Ju, X. F. \& Mirza, S. S. (2012). Chinese Competitiveness and Growth Sustainability. International Journal of Business and Social Science, 3(3).

Liao, C. (2005). The Governance Structure of Chinese Firms: Innovation, Competitiveness, and Growth in Dual Economy. Springer.

MacFarlan, M., Edison, H. \& Spatafora, N. (2003). World Economic Outlook, chapter 3. www.imf.org/external/pubs/ft/weo/2003/01/pdf/chapter3.pdf

Montinola, G., Qian, Y. \& Weingast, R. B. (1996). Federalism, Chinese Style: The political basis for economic success.

North, D. C. (1990). Institutions, Institutional change and economic performance. Cambridge University Press. Cambridge.

Orr, G. \& Roth, E. (2013). China's innovation engine picks up speed. McKinsey Quarterly www.mckinsey.com

Pan, S. Y. (2011). Education abroad, Human capital development, and National competitiveness: China's Brain gain strategies. Frontiers of Education in China, 6(1), 106-138.

Porter, E. M. (1990). The competitive advantage of nations. Harvard Business Review, 3, 73-93.

Zhang, J., Ebbers, H. \& Mulder, R. (2012). Competitiveness of Chinese Industries - A Comparison with the EU. www.ccsenet.org/journal/index.php/res/article/.../10408. 